\title{
PERBAIKAN KINERJA PERUSAHAAN DENGAN METODE KRITERIA PENILAIAN KINERJA UNGGUL (KPKU BUMN)
}

\author{
Tri Joko Wibowo ${ }^{1)}$ \\ Jurusan Teknik Industri, Fakultas Teknik \\ Universitas Serang Raya,Taman Drangong, Serang, Banten, 42111, Indonesia \\ E-mail : rb.bowo@gmail.com
}

\begin{abstract}
A b strak
$P T X$ adalah perusahaan yang bergerak di bidang jasa. Seiring dengan perkembangan bisnis perusahaan dan dinamika bisnis eksternal, perusahaan bermaksud melakukan penilaian kondisi bisnis perusahaan. Kondisi bisnis perusahaan akan menjadi dasar bagi perusahaan untuk melakukan perencanaan bisnis ke depan dan sekaligus mengelola bisnis saat ini. Proses penilaian dilakukan dengan penerapan kriteria penilaian kinerja unggul (KPKU) BUMN. KPKU BUMN sendiri adalah adopsi dan adaptasi kriteria Malcolm Baldrige yang berasal Amerika Serikat. Ouput dari metode KPKU adalah skor dan band skor, yang menggambarkan kinerja perusahaan secara umum. Hasil penerapan KPKU telah menghasilkan perbaikan kinerja dimana pada tahun 2010, skor Perusahaan sebesar 233,1 (early development) dan setelah melakukan perbaikan, skor pada tahun 2013 sebesar 324 (early result), pada tahun 2017 dilakukan assesment dengan skor 441.25(early development).
\end{abstract}

Kata Kunci: early result, early development, malcolm baldrige, kpku.

\section{PENDAHULUAN}

Persaingan bisnis dari masa ke masa semakin ketat. Perusahaan perlu melakukan perbaikan pada aspek-aspek yang penting dan signifikan bagi perusahaan ke depan. Perusahaan tidak cukup mempunyai kinerja yang baik untuk menang dalam persaingan bisnis, tetapi perusahaan harus memiliki kinerja yang ekselen dibandingkan dengan pesaing-pesaing bisnis yang ada. Salah satu kriteria yang bisa dipakai oleh perusahaan untuk mempunyai kinerja yang ekselen adalah kriteria KPKU. KPKU merupakan singkatan dari Kriteria Penilaian Kinerja Unggul. KPKU juga merupakan adopsi dan adaptasi dari kriteria Malcolm Baldrige oleh BUMN. Di bawah ini adalah kerangka kesisteman KPKU BUMN :

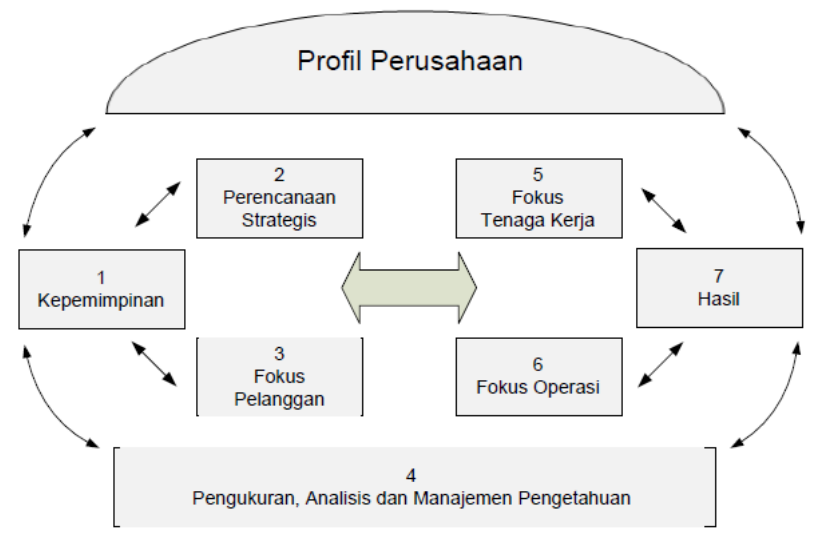

Gambar 1. Kerangka Kesisteman KPKU BUMN

Sumber : Kementerian Badan Usaha Milik Negara RI, 2015, Kriteria Penilaian Kinerja Unggul BUMN, Deputi Bidang Infrastruktur Bisnis 
KPKU BUMN dirancang untuk mendorong dan membantu BUMN mencapai visi, misi dan tujuan perusahaan, meningkatkan kinerja secara berkelanjutan dan dimilikinya keunggulan daya saing perusahaan melalui keselarasan atas rencana perusahaan, proses-proses yang dijalankan, pengambilan keputusan, fokus karyawan/tenaga kerja dan seluruh tindakan yang pada akhirnya dapat ditunjukkan dengan pencapaian hasil yang unggul. KPKU BUMN juga dirancang untuk dapat digunakan sebagai alat penilaian yang holistik mengukur posisi perusahaan dan menunjukkan apa yang diperlukan oleh perusahaan kedepan untuk perbaikan/peningkatan kinerja dalam jangka panjang. KPKU BUMN didalamnya berisi pertanyaan-pertanyaan yang terdiri dari tujuh aspek (kategori) penting yang harus diperhatikan untuk mencapai keberhasilan perusahaan terkait dengan pengelolaan proses dan hasil yang unggul, yaitu: Kepemimpinan, Perencanaan Strategis, Fokus Pelanggan, Pengukuran, Analisis dan Manajemen Pengetahuan, Fokus Tenaga Kerja, Fokus Operasi dan Hasil. Kriteria KPKU BUMN dirancang agar perusahaan fokus pada hasil, yaitu hasil-hasil yang berkaitan dengan keunggulan perusahaan di industrinya antara lain adalah kinerja utama produk (layanan) dan proses, kinerja pelanggan, kinerja SDM (tenaga kerja), kinerja kepemimpinan dan tatakelola, serta kinerja keuangan dan pasar.

Kriteria KPKU BUMN bersifat non preskriptive dan adaptive. Maksud non preskriptive adalah Penerapan KPKU BUMN tidak mewajibkan perusahaan untuk "seharusnya" memiliki struktur organisasi tertentu seperti Unit Perencanaan, Unit Pengelola Etika, Unit Pengelola Mutu atau fungsi-fungsi lainnya yang berdiri sendiri. KPKU BUMN juga tidak mewajibkan perusahaan harus menerapkan ISO, Lean, Six Sigma, Balanced Score Card, dll. Hal ini mengingat, bahwa berbeda perusahaan berbeda pula kondisi, ukuran dan tantangan yang dihadapinya. KPKU BUMN memiliki 8 band/tingkatan untuk menggolongkan tingkat ekselen dari suatu organisasi. Masingmasing band memiliki indikator rentang capaian skor. Level band KPKU sebagai berikut early development (0-275), early result (276-375), early improvement (376-475), good performance (476-575), emerging industry leader (576-675), industry leader (676-775), benchmark leader (775-875) dan world leader (876-1000).

PT X memandang kriteria KPKU BUMN sangat cocok untuk mendiagnosa kondisi kinerja eksisting. Oleh karena itu, paper ini mengulas singkat bagaimana PT X menggunakan kriteria KPKU BUMN sebagai alat untuk memperbaiki kinerja perusahaan supaya mengarah pada kinerja yang ekselen di masa mendatang.

\section{METODE PENELITIAN}

Tahapan di dalam melakukan perbaikan kinerja berbasis KPKU sebagai berikut :

1. Melakukan assesment KPKU yang dilakukan oleh pihak eksternal perusahaan.

2. Melakukan review terhadap dokumen feedback report dari assesor KPKU

3. Menyusun SK Tim KPKU Perusahaan

4. Menetapkan urutan OFI prioritas untuk segera disusun program kerja tindak lanjut

5. Menetapkan target perbaikan OFI dan menyusun program perbaikan

6. Melakukan implementasi program tindak lanjut OFI

\section{HASIL DAN PEMBAHASAN}

Tahapan awal yang dilakukan perusahaan adalah mengundang pihak luar pada tahun 2010 untuk melakukan assesment. Dari proses assesment, perusahaan mendapatkan dokumen feedback report yang berisi skor KPKU, most strength, strength, most ofi dan ofi. Strength adalah hal-hal yang dipandang merupakan kekuatan yang dimiliki oleh perusahaan dan perlu dipelihara supaya terus menjadi keunggulan perusahaan di masa mendatang. Sedangkan ofi (opportunity for improvement) adalah hal-hal yang masih perlu dilakukan perbaikan oleh perusahaan. Skor 2010 yang berhasil dicapai oleh perusahaan adalah 233,1 artinya perusahaan masih berada band skor yang paling bawah yaitu early development.

Tahapan kedua, perusahaan melakukan review atas dokumen feedback report. Review perlu dilakukan karena seringkali ada kesenjangan pemahaman diantara para pemilik proses bisnis di perusahaan terhadap pernyataan yang tertuang didalam feedback report. Sekaligus juga

JIM, Vol. 4, No. 1, Januari 2019, pp.7-12 
menyamakan persepsi diantara para pemilik proses. Penyamaan persepsi ini menjadi penting karena sesuai dengan esensi bisnis ekselen adalah integrasi antar proses. Integrasi antar proses tidak akan terjadi tanpa ada cara berpikir yang sama di dalam mengelola proses bisnis.

Tahap ketiga, perusahaan menyusun SK Tim KPKU. Berdasarkan SK ini, tim KPKU bertugas untuk menindaklanjuti OFI 2010, menyusun dokumen kuesioner KPKU meliputi profile organisasi, kuesioner kategori proses dan kuesioner kategori hasil. Tim KPKU merupakan tim task force yang memastikan seluruh OFI telah disusun program kerja tindak lanjut beserta monitoringnya.

Tahap keempat-kelima, Tim KPKU mulai membedah dokumen feedback report dan mengurutkan OFI sesuai prioritas tindakan perbaikan. Prioritas OFI digolongkan menjadi 4 yaitu sangat berpengaruh, berpengaruh, kurang berpengaruh dan tidak berpengaruh. Dasar penggolongan tersebut adalah sejauh mana signifikansi pengaruh perbaikan bagi kinerja perusahaan jika suatu OFI ditindaklanjuti. Untuk memudahkan proses diskusi, tim KPKU menggunakan template sebagaimana ditunjukkan dalam Tabel 1. Contoh Template Monitoring Progress OFI KPKU.

Tahap keenam, perusahaan menjalankan program perbaikan tindak lanjut OFI. Program perbaikan dilakukan di masing-masing unit kerja pemilik proses. Dalam hal ini, tim KPKU berperan mengkoordinasikan dan menkonsolidasikan hasil-hasil progress perbaikan. Progress implementasi perbaikan digolongkan menjadi 6 yaitu draft, implementasi $<50 \%$, implementasi $<75 \%$, implementasi $>75 \%$, implementasi $100 \%$ dan sudah didokumentasikan (prosedur atau SOP). Tujuan akhir dari program perbaikan OFI adalah proses bisnis yang telah teruji dan terstandarisasi. Hal tersebut bisa dilihat dari dokumentasi proses bisnis dalam sebuah prosedur atau SOP perusahaan.

Tahap ketujuh, perusahaan melakukan evaluasi diri atau assesment internal untuk mempersiapkan proses assesment eksternal. Dalam proses ini, perusahaan menyusun 3 dokumen yaitu profile organisasi, kuesioner ADLI dan kuesioner Hasil.

Profile organisasi berisi mengenai lingkungan organisasi (meliputi : produk yang ditawarkan, visi misi, profile, tenaga kerja, asset, persyaratan regulasi), hubungan organisasi (meliputi : struktur organisasi, pelanggan \& pemangku kepentingan, pemasok \& mitra, lingkungan kompetitif (meliputi : posisi daya saing, perubahan situasi persaingan, data pembanding), konteks strategis dan pengukuran kinerja.

Kuesioner ADLI berisi jawaban perusahaan terhadap setiap kriteria yang ditanyakan dalam KPKU. Kuesioner ADLI ini meliputi 6 kategori proses yaitu kat 1. kepemimpinan, kat 2. perencanaan strategis, kat 3. fokus pelanggan, kat 4. pengukuran, analisis dan manajemen pengetahuan, kat 5 . fokus tenaga kerja dan kat 6 . fokus operasional. Setiap pertanyaan di dalam kriteria proses harus dijawab dengan ADLI. ADLI kependekan dari Approach, Deploy, Learning, Integration. Approach menunjukan uraian proses sistematis (input, proses dan output) yang ada dalam jawaban setiap kriteria, deploy menunjukkan bagaimana approach dijalankan, learning menunjukan bagaimana approach dievaluasi/diperbaiki dan integration menunjukkan bagaimana antar approach saling diselaraskan dan diintegrasikan. ADLI memiliki rentang skor dari 1 hingga 6. Rentang tersebut menggambarkan sejauh mana proses/approach yang dimiliki oleh perusahaan telah mencapai level kematangan tertentu.

Kuesioner hasil berisi capaian-capaian kinerja perusahaan dalam 5 hal, yaitu kinerja produk dan proses, kinerja fokus pelanggan, kinerja fokus tenaga kerja, kinerja kepemimpinan dan tata kelola, dan kinerja finansial dan pasar. Contoh kuesioner hasil ditunjukkan dalam Gambar 1. Contoh Kategori Hasil 7.1. Kinerja Produk dan Layanan. 
Tabel 1. Contoh Template Monitoring Progress OFI KPKU

\begin{tabular}{|c|c|c|c|c|c|c|c|c|}
\hline \multicolumn{2}{|r|}{ IMPLEMENTASI KPKU } & \multicolumn{3}{|c|}{ PROGRES OFI KPKU 2013} & \multicolumn{4}{|c|}{$\begin{array}{l}\text { No } \\
\text { Diterbitkan tgl : } \\
\text { Halaman }:\end{array}$} \\
\hline No & KATAGORI & OPPORTUNITY OF IMPROVEMENT & TINDAKAN PERBAIKAN & PIC & LINK & $\begin{array}{l}\text { ESTIMASI } \\
\text { WAKTU }\end{array}$ & $\begin{array}{l}\text { PROG } \\
\text { RESS }\end{array}$ & $\begin{array}{l}\text { PRIOR } \\
\text { ITAS }\end{array}$ \\
\hline \multicolumn{9}{|c|}{ KAT.1 KEPEMIMPINAN } \\
\hline $1.1 \mathrm{a}(1)$ & $\begin{array}{l}\text { Bagaimana pemimpin senior } \\
\text { menetapkan, menjabarkan, visi,misi, } \\
\text { tatanilai perusahaan kpd stakeholder }\end{array}$ & $\begin{array}{l}\text { Visisi tidak diiringi dengan penetapan } \\
\text { indicator keberhasilan dan milestone } \\
\text { pencapaiannya. }\end{array}$ & $\begin{array}{l}\text { Menetapkan visi,misi, } \\
\text { kompetensi inti, model dan } \\
\text { proses bisnis dengan tahapan } \\
\text { pencapaiannya }\end{array}$ & & & & 5 & 1 \\
\hline \multicolumn{9}{|c|}{ KAT.2 PERENCANAAN STRATEGIS } \\
\hline $2.1 \mathrm{a}(1)$ & \begin{tabular}{|l|} 
Bagaimana organisasi \\
meng"conduct" perencanaan \\
strategis (proses utama, partisipasi \\
utama, kompetensi inti)
\end{tabular} & $\begin{array}{l}\text { Meskipun Perusahaan telah } \\
\text { menentukan kompetensi inti dan } \\
\text { tantangan strategis namun } \\
\text { evaluasinya tidak dilakukan secara } \\
\text { berkala }\end{array}$ & $\begin{array}{l}\text { Merevisi kompetensi korporasi } \\
\text { dan individu, Evaluasi } \\
\text { kompetensi inti secara berkala }\end{array}$ & & & & 5 & 1 \\
\hline \multicolumn{9}{|c|}{ KAT.3 FOCUS PELANGGAN } \\
\hline $3.1 \mathrm{a}(1)$ & $\begin{array}{l}\text { Bagaimana organisasi mendapatkan } \\
\text { informasi pelanggan yang berbeda- } \\
\text { beda, dan bagaimana } \\
\text { menindaklanjutinya }\end{array}$ & $\begin{array}{l}\text { Walapun Perusahaan telah } \\
\text { mkelakukan mengumpulkan } \\
\text { informasi dari pelanggan namun, } \\
\text { belum terhadap mantan customer } \\
\text { saat ini dan pelanggan potensial dan } \\
\text { pelanggan pesaing }\end{array}$ & $\begin{array}{l}\text { Membuat sistem informasi } \\
\text { pelanggan untuk } \\
\text { mengumpulkan informasi } \\
\text { (keluhan, persyaratan, } \\
\text { kebutuhan, feedback) } \\
\text { pelanggan. } \\
\end{array}$ & & & & 1 & 1 \\
\hline \multicolumn{9}{|c|}{ KAT.4 PENGUKURAN, ANALISA \& KM } \\
\hline $4.1 \mathrm{a}(2)$ & $\begin{array}{l}\text { Bagaimana menggunakan informasi } \\
\text { permbanding utk mendukung } \\
\text { keputusan? }\end{array}$ & $\begin{array}{l}\text { Perusahaan belum memiliki metode } \\
\text { dalam memilih dan memastikan } \\
\text { efektifitas pemanfaatan data dan } \\
\text { informasi pembanding yang penting }\end{array}$ & $\begin{array}{l}\text { Menyusun sistem bencmarking } \\
\text { dalam penetapan proyeksi } \\
\text { kinerja organisasi dibandinglan } \\
\text { dengan pesaing }\end{array}$ & & & & 1 & 2 \\
\hline $\begin{array}{l}\stackrel{=}{\equiv} \\
\equiv \\
\equiv \\
\equiv\end{array}$ & 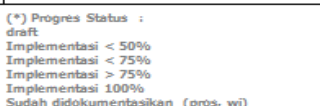 & 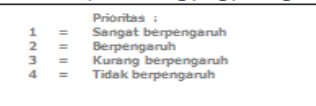 & & & & & & \\
\hline
\end{tabular}

Tabel 2. Contoh Kuesioner ADLI Kat 1. Kepemimpinan

\section{Kategori 1. Kepemimpinan}

Kuesioner Bagian II (Kepemimpinan)

\section{Sub Kategori 1.1. Kepemimpinan Senior}

a. Visi, Tata nilai dan Misi

(1) Visi dan Tata Nilai

\begin{tabular}{|c|c|c|c|c|c|}
\hline & & Approach (A6) & Deployment (D6) & Learning (L4) & Integration (14) \\
\hline a.1.3 & \begin{tabular}{|l} 
Bagaimana tindakan \\
pimpinan senior \\
dalam \\
mencerminkan \\
komitmennya \\
terhadap tata nilai \\
perusahaan?
\end{tabular} & $\begin{array}{l}\text { Input: tata nilai perusahaan } \\
\text { Proses : Menyelaraskan tata nilai perusahaa, } \\
\text { membuat dan mensosialisasikan buku paduan } \\
\text { code of conduct dan menerapkan butir tata } \\
\text { nilai perusahaan dalam sistem penilaian } \\
\text { kinerja karyawan pada item perilaku karyawan } \\
\text { Output : perusahaan yang beretika bagus } \\
\text { dalam berbisnis } \\
\text { Indikator : Pencapaian skor penilaian budaya } \\
\text { kerja karyawan }\end{array}$ & $\begin{array}{l}\text { Direksi menugaskan divisi corporate } \\
\text { transformation untuk menyusun dan } \\
\text { menyelaraskan tata nilai perusahaan. Div. CT } \\
\text { menyusun draft tata nilai untuk kemudian } \\
\text { disahkan oleh Direksi. Divisi corporate } \\
\text { transformation memastikan bahwa buku tata } \\
\text { nilai yang sudah disahkan ditandatangani oleh } \\
\text { masing-masing karyawan sebagai tanda } \\
\text { komitmen terhadap tata nilai yang dimiliki oleh } \\
\text { Perusahaan. Mengimplementasikan } \\
\text { "innovation day" sebagai bentuk komitmen } \\
\text { manajemen terhadap tatanilai perudahaan } \\
\text { (inovasi dan inspiring). }\end{array}$ & $\begin{array}{l}\text { Setiap tahun human capital melakukan } \\
\text { penilaian budaya kerja karyawan } \\
\text { melalui MSBK. Teknisnya yaitu dengan } \\
\text { mendistribusikan kuesioner ke } \\
\text { karyawan, selama beberapa hari } \\
\text { karyawan diberikan kesempatan untuk } \\
\text { mengisi kuesioner dan dikirimkan } \\
\text { kembali ke HC. Melalui kuesioner } \\
\text { karyawan diminta menilai dirinya } \\
\text { sendiri, menilai partner kerja dan } \\
\text { menilai atasan langsung. Kuesioner } \\
\text { berisi pertanyaan mengenai } \\
\text { implementasi tata nilai perusahaan. } \\
\text { Program "innovation day" telah dijadwal } \\
\text { dalam Calender of Event Perusahaan. }\end{array}$ & $\begin{array}{l}\text { Hasil penilaian budaya kerja karyawan } \\
\text { akan berdampak pada lingkungan } \\
\text { budaya kerja perusahaan yang } \\
\text { semakin baik. } \\
\\
\end{array}$ \\
\hline
\end{tabular}

JIM, Vol. 4, No. 1, Januari 2019, pp.7-12 
KATEGORI HASIL $(7.1-7.5)$
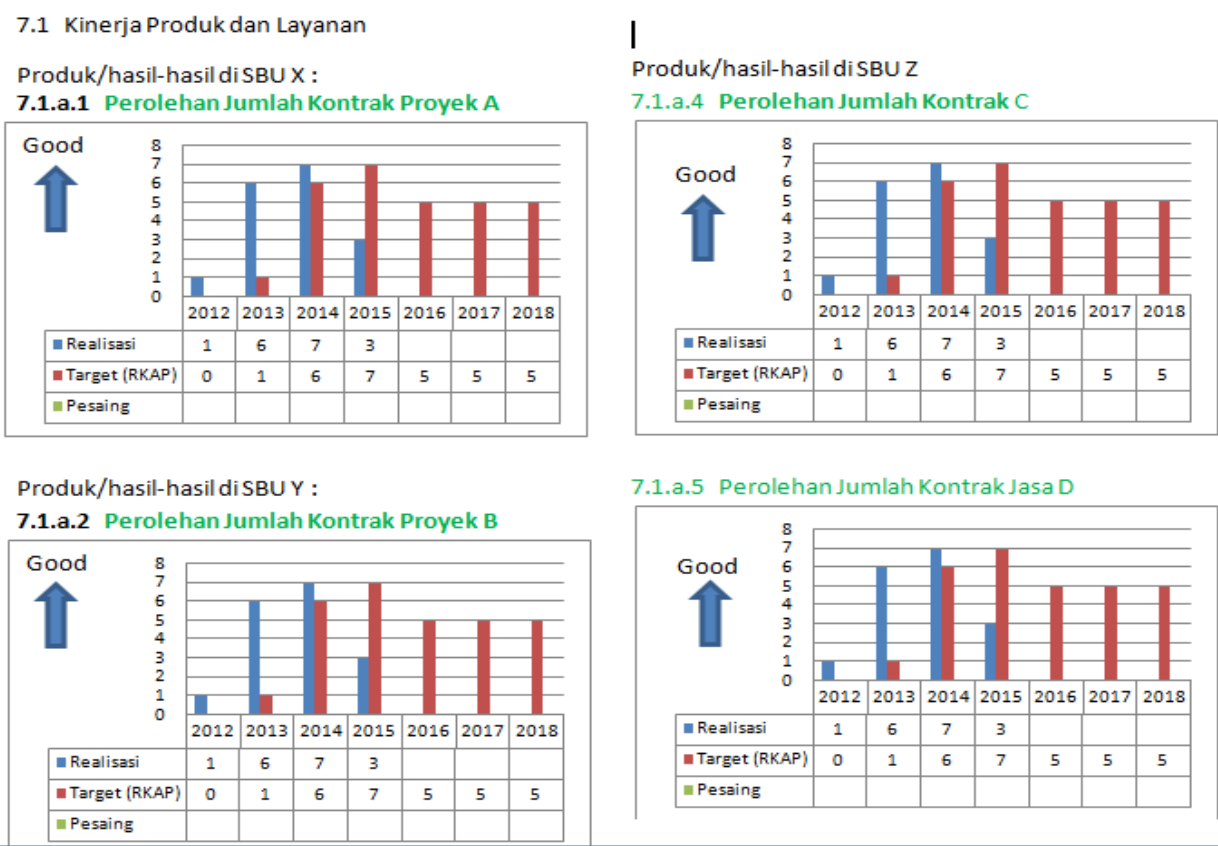

Gambar 2. Contoh Kategori Hasil 7.1. Kinerja Produk dan Layanan

Di bawah ini adalah perbandingan skor perusahaan berbasis kinerja ekselen (Malcolm/KPKU BUMN) :

Tabel 3. Skor Sebelum dan Sesudah dilakukan perbaikan

\begin{tabular}{|c|c|c|c|c|c|c|}
\hline \multirow{2}{*}{ SKT } & \multicolumn{2}{|c|}{$\begin{array}{c}\text { Assesment } \\
\text { Malcolm } 2010\end{array}$} & \multicolumn{2}{|c|}{$\begin{array}{c}\text { Assesment } \\
\text { KPKU } 2013\end{array}$} & \multicolumn{2}{|c|}{$\begin{array}{c}\text { Assesment } \\
\text { KPKU } 2017\end{array}$} \\
\hline & $\begin{array}{c}\% \\
\text { skor }\end{array}$ & $\begin{array}{l}\text { Point } \\
\text { Skor }\end{array}$ & $\begin{array}{c}\% \\
\text { Skor }\end{array}$ & $\begin{array}{l}\text { Point } \\
\text { Skor }\end{array}$ & $\begin{array}{c}\% \\
\text { Skor }\end{array}$ & $\begin{array}{l}\text { Point } \\
\text { Skor }\end{array}$ \\
\hline 1.1 Kepemimpinan Senior & 40 & 28 & 35 & 24,5 & 55 & 38,5 \\
\hline 1.2 Tata Kelola \& Tanggung Jawab Kemasyarakatan & 40 & 20 & 35 & 17,5 & 50 & 25 \\
\hline 2.1 Pengembangan Strategi & 40 & 16 & 35 & 14 & 50 & 20 \\
\hline 2.2 Implementasi Strategi & 35 & 15,75 & 35 & 15,75 & 50 & 22,5 \\
\hline 3.1 Suara Pelanggan & 25 & 11,25 & 35 & 15,75 & 45 & 20,25 \\
\hline 3.2 Keterikatan Pelanggan & 30 & 12 & 35 & 14 & 45 & 18 \\
\hline 4.1 Pengukuran, Analisis dan Kinerja Org & 30 & 13,6 & 35 & 15,75 & 45 & 20,25 \\
\hline 4.2 Pengelolaan Informasi, Pengetahuan & 25 & 11,25 & 35 & 15,75 & 45 & 20,25 \\
\hline 5.1 Lingkungan Tenaga Kerja & 30 & 12 & 35 & 14 & 45 & 18 \\
\hline 5.2 Keterikatan Tenaga Kerja & 25 & 11,25 & 35 & 15,75 & 45 & 20,25 \\
\hline 6.1 Sistem Kerja & 30 & 10,5 & 35 & 15,75 & 45 & 20,25 \\
\hline 6.2 Proses Kerja & 25 & 12,5 & 35 & 14 & 45 & 18 \\
\hline 7.1 Hasil-hasil Produk & 10 & 10 & 30 & 33 & 40 & 44 \\
\hline 7.2 Fokus Pelanggan & 10 & 7 & 35 & 31,5 & 40 & 34 \\
\hline 7.3 Fokus Tenaga Kerja & 20 & 14 & 30 & 24 & 40 & 34 \\
\hline 7.4 Kepemimpinan & 20 & 14 & 20 & 16 & 40 & 32 \\
\hline 7.5 Keuangan dan Pasar & 20 & 14 & 30 & 27 & 40 & 36 \\
\hline & & 233,1 & & 324 & & 441,25 \\
\hline
\end{tabular}




\section{KESIMPULAN}

a) Kriteria KPKU dapat dipergunakan sebagai panduan bagi perusahaan untuk melakukan perbaikan kinerja perusahaan secara menyeluruh

b) Perbaikan kinerja dilakukan dengan melakukan tindak lanjut terhadap pada hasil assesment KPKU berupa most OFI dan OFI.

c) Perusahaan memperbaiki skor dan band dari 233,1 (early development) pada tahun 2010 menjadi 324 (early result) pada tahun 2013 dan pada tahun 2017 menjadi 441,25 (early development)

\section{DAFTAR PUSTAKA}

Forum Ekselen BUMN, 2014, Materi Training Intrepretasi KPKU

Kementerian Badan Usaha Milik Negara RI, 2015, Kriteria Penilaian Kinerja Unggul BUMN, Deputi Bidang Infrastruktur Bisnis. 